\title{
Instrumentation and Assay Procedures for Verification of the Radionuclide Content of Low-Level Waste Packages
}

\author{
R. L. Brodzinski
}

September 1983

Prepared for the U.S. Department of Energy under Contract DE-AC06-76RLO 1830

Pacific Northwest Laboratory Operated for the U.S. Department of Energy by Battelle Memorial Institute 


\title{
DISCLAIMER
}

This report was prepared as an account of work sponsored by an agericy of the United States Government. Neither the United States Government nor any agency thereof, nor any of their employees, makes any warranty, express or implied, or assumes any legal liability or responsibility for the accuracy, completeness, or usefulness of any information, apparatus, product, or process disclosed, or represents that its use would not infringe privately owned rights. Reference herein to any specific commercial product, process, or service by trade name, trademark, manufacturer, or otherwise, does not necessarily constitute or imply its endorsement, recommendation, or favoring by the United States Government or any agency thereof. The views and opinions of authors expressed herein do not necessarily state or reflect those of the United States Government or any agency thereof.

\author{
PACIFIC NORTHWEST LABORATORY \\ operated by \\ BATTELLE \\ for the \\ UNITED STATES DEPARTMENT OF ENERGY \\ under Contract DE-AC06-76RLO 1830
}

Printed in the United States of America Available from

National Technical Information Service

United States Department of Commerce

5285 Port Royal Roar

Springfield, Virginia 22161

NTIS Price Codes

Microfiche $\mathrm{A} 01$

\begin{tabular}{|c|c|}
\hline \multicolumn{2}{|c|}{ Printed Copy } \\
\hline Pages & $\begin{array}{l}\text { Price } \\
\text { Codes }\end{array}$ \\
\hline $001-025$ & $\mathrm{~A} 02$ \\
\hline $026-050$ & $\mathrm{~A} 03$ \\
\hline $051-075$ & $\mathrm{AO4}$ \\
\hline $076-100$ & A05 \\
\hline $101-125$ & A06 \\
\hline $126-150$ & $\mathrm{~A} 07$ \\
\hline $151-175$ & A08 \\
\hline $176-200$ & $\mathrm{~A} 09$ \\
\hline $201-225$ & A010 \\
\hline $226-250$ & A011 \\
\hline 251.275 & A012 \\
\hline $276-300$ & $\mathrm{~A} 013$ \\
\hline
\end{tabular}




\section{R. L. Brodzinski}

September 1983

Prepared for the U.S. Department of Energy under Contract DE-AC06-76RLO 1830

Pacific Northwest Laboratory Richland, Washington 99352 


\section{TABLE OF CONTENTS}

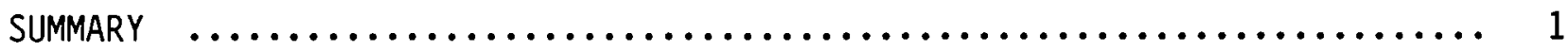

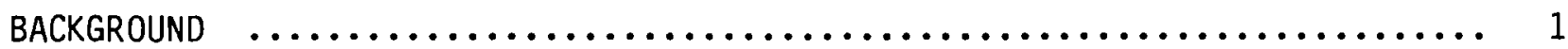

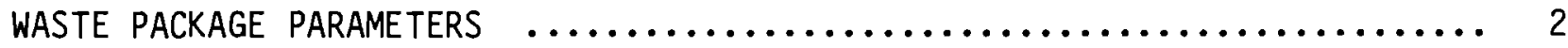

RADIOISOTOPES $\quad \ldots \ldots \ldots \ldots \ldots \ldots \ldots \ldots \ldots \ldots \ldots \ldots \ldots \ldots \ldots \ldots \ldots \ldots \ldots \ldots$

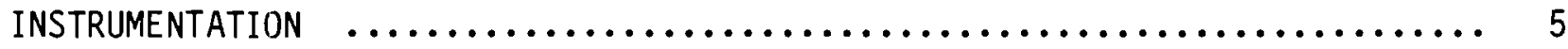

MEASUREMENTS AND CALIBRATIONS $\ldots \ldots \ldots \ldots \ldots \ldots \ldots \ldots \ldots \ldots \ldots \ldots \ldots \ldots \ldots \ldots$

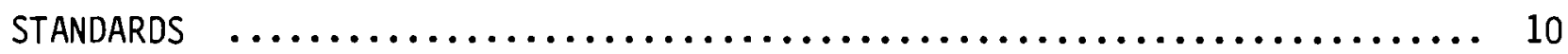

REFERENCES $\quad \ldots \ldots \ldots \ldots \ldots \ldots \ldots \ldots \ldots \ldots \ldots \ldots \ldots \ldots \ldots \ldots \ldots \ldots \ldots \ldots \ldots \ldots$

DISTRIBUTION $\ldots \ldots \ldots \ldots \ldots \ldots \ldots \ldots \ldots \ldots \ldots \ldots \ldots \ldots \ldots \ldots \ldots \ldots \ldots \ldots \ldots$ 


\section{INSTRUMENTATION AND ASSAY PROCEDURES FOR \\ VERIFICATION OF THE RADIONUCLIDE CONTENT OF \\ LOW-LEVEL WASTE PACKAGES}

\section{SUMMARY}

The preferred embodiment of waste package assay instrumentation for verification of the radionuclide content is a high resolution germanium diode garma-ray spectrometer incorporated in a segmented gamma scanner and a passive neutron interrogation system for measurement of the neutrons emitted spontaneously from a waste package. The selection criteria and rationale for this choice are discussed. Assembly and operation procedures for the instrumentation are recommended, and methods for data acquisition and reduction are given. The choice of radioisotopes for fabrication of calibration standards is ${ }^{60} \mathrm{Co}$ at $\sim 10 \mathrm{mCi} / \mathrm{m}^{3},{ }^{90} \mathrm{Sr}$ at $\sim 10 \mathrm{mCi} / \mathrm{m}^{3},{ }^{134} \mathrm{Cs}$ at $s 14 \mathrm{mCi} / \mathrm{m}^{3},{ }^{137} \mathrm{Cs}$ at $s 15 \mathrm{mCi} / \mathrm{m}^{3}$, and transuraric alpha activity at $\sim 10 \mathrm{nCi} / \mathrm{g}$. Suggested matrix materials are given.

\section{$\underline{\text { BACKGROUND }}$}

The objective of this research program was to organize, apply, and develop as required, instrumentation for assaying the radionuclide content of waste packages received by land burial operators, both to verify the data provided by the generator/shipper and to provide the most accurate records possible of buried materials. Furthermore, the waste classification requirements imposed under 10 CFR 61 demand additional assurance that specific radioisotope concentrations are known to be within certain limits. The technology to assay waste packages within these confines is not currently in routine use by generators/shippers. The effects of 10 CFR 61 on nuclear power plant operation were documented in the EPRI report NP-2734 which found that "meeting the waste identification needs of 10 CFR 61 will require a significant analytic effort beyond present plant practice."

In order to alleviate any potential crisis among waste generators/shippers and in order to clarify the overall procedures which may be used by licensees to determine the presence and concentrations of the radionuclides listed in 10 CFR 61.55, the NRC Low-Level Waste Licensing Branch has prepared technical 
position papers on waste classification and waste form. The NRC considers reasonable accuracy for determining measured or inferred radionuclide concentrations to be plus or minus an order of magnitude. They further recognize at least four basic methods which may be used individually or in combination to determine these concentrations: 1) materials accountability, 2) classification by source, 3) gross radioactivity measurements, and 4) direct measurement of individual radionuclides.

Obviously, it would be ideal if all radionuclides listed in 10 CFR 61 could be analyzed simultaneously, quantitatively, and nondestructively in a sealed waste package. Just as obviously, that is not possible. Hence, it is advisable that all those radionuclides which can be quantitatively analyzed, be determined to the maximum practical accuracy in order that those radionuclide concentrations which are to be inferred from the measured ones have a greater probability of remaining within the guidelines for overall uncertainty.

An accurate inventory of the radionuclide content of a disposal site will provide a useable source term for modeling efforts attempting to predict the effectiveness of confinement or the magnitude of potential releases.

\section{WASTE PACKAGE PARAMETERS}

Unquestionably, the most important aspect of radioactive waste disposal by 1 and burial is the ability to confine the wastes until they have decayed to innocuous levels. Proper operation of a land disposal site with respect to long-term management can be generally defined as the efficient interment of radioactive wastes in a manner such that hazardous quantities of radionuclides never enter the biosphere under normal climatic conditions or from predictable catastrophic events. This means that the combination of engineered barriers and geological containment should be adequate to confine the wastes for periods of time far beyond the anticipated operation and maintenance period of a disposal site. Through proper choice of waste form, matrix material, waste package, trench construction, and terrestrial geology, such confinement can probably be assured.

Low-level waste disposal activities at DOE sites are not as well documented as those at commercial disposal sites. Consequently, information on waste packages, matrices, and radionuclide concentrations used in this report 
were obtained from readily available data to be found in DOE LOW Level Waste Management Program sponsored surveys of commercial activities. The relative radionuclide concentrations and disposal considerations are similar for both defense and commercial waste. The waste packages and matrices, however, are not as well defined at defense sites as they are at commercial sites, and in order to make maximum use of the assay procedures and instrumentation described in this report, defense sites would have to adopt more uniform packaging procedures.

Based on data reported in the Massachusetts Low-Level Radioactive Waste Management Survey, DOE/LLW-19T, approximately $50 \%$ by volume of the low-level waste being generated today is shipped in $4^{\prime} \times 4^{\prime} \times 8^{\prime}$ plywood boxes (or similar containers including $4^{\prime} \times 4^{\prime} \times 7^{\prime}$ plywood boxes, steel boxes, fiberglass boxes, desigrated WIPP containers, etc.), approximately $33 \%$ in 55 gallon drums, and approximately $8 \%$ in 30 gallon drums with the balance being in containers designated "other." Precision waste package assay instrumentation should not be expected to accept all conceivable waste package geometries. Standardization of waste packages would facilitate assay, provide additional barriers to mobilization and migration of the wastes, and aid in stabilization of the disposal site. Waste package assay instrumentation development has been concentrated on the $4^{\prime} \times 4^{\prime} \times 8^{\prime}$ boxes and the steel drums, and generators should make efforts to package all wastes in one of these three configurations.

The choice of a waste form or matrix material is not as clear cut as the choice of the package itself. According to the Massachusetts Survey, no single waste form or matrix material comprised a significant fraction of the total. In fact, the majority of waste forms or matrix materials are not even identifiable. Some improvements in waste form standardization will result from the requirements of 10 CFR 61 and the NRC Technical Position on Waste Form. The NRC also recommends a process control program to assure the consistent solidification of liquid waste and provides requirements in the NRC Standard Review Plan 11.4, "Solid Waste Management Systems," (NUREG-0800) and its accompanying Branch Technical Position ETJB 11-3, "Design Guidance for Solid Waste Management Systems Installed in Light-Water-Cooled Nuclear Power Reactor Plants." Consistent use of a minimum number of matrix materials would simplify the assay process and result in more accurate determinations of radionuclide concentrations. 


\section{RADIOISOTOPES}

In order to make reasonable predictions of management potentials, it will be necessary to know the concentrations and total activities of the radionuclides present in the waste package. Again, however, it is expedient to consider only those radionuclides which present a long-term potential hazard. Relatively short-lived nuclides or those which represent minimal biological hazard can realistically be presumed to be containable for periods of time sufficient to render them innocuous. Radionuclides with half-lives less than five years are lumped together into a single category in $10 \mathrm{CFR} 61$ while $3 \mathrm{H}$, ${ }^{14} \mathrm{C},{ }^{59} \mathrm{Ni}, 60 \mathrm{Co}, 6{ }^{\mathrm{Ni}}, 90 \mathrm{Sr}, 94 \mathrm{Nb},{ }^{99} \mathrm{Tc},{ }^{129} \mathrm{I},{ }^{137} \mathrm{Cs}$, and transuranics are classified individually.

The Massachusetts Survey indicates that greater than $99 \%$ of the activity in shipped low-level waste is comprised of ${ }^{3} \mathrm{H},{ }^{14} \mathrm{C},{ }^{55} \mathrm{Fe},{ }^{60} \mathrm{Co},{ }^{90} \mathrm{Sr},{ }^{134} \mathrm{Cs}$, ${ }^{137} \mathrm{Cs}$, and transuranics, and the 1981 State-by-State Assessment of Low-Level Radioactive Wastes Shipped to Commercial Disposal Sites, DOE/LLW-15T, lists the typical radionuclides contained in low-level wastes as $3 \mathrm{H},{ }^{14} \mathrm{C}, 51 \mathrm{Cr}, 54 \mathrm{Mn}$, ${ }^{58} \mathrm{Co},{ }^{60} \mathrm{Co}, 65 \mathrm{Zn}, 125 \mathrm{I}, 131_{\mathrm{I}},{ }^{134} \mathrm{Cs}, 137 \mathrm{Cs},{ }^{192} \mathrm{Ir}$, and $238 \mathrm{U}$. In addition to these nuclides, 93 Mo has also been identified as a radioisotope having potential impact on the management of a low-level waste disposal site.

It is prudent to el iminate those isotopes from the above lists having half-lives less than one year in considering qualifications and requirements for assay instrumentation. Of the remaining radionuclides, ${ }^{3} \mathrm{H},{ }^{14} \mathrm{C},{ }^{55} \mathrm{Fe}$, $59 \mathrm{Ni}, 63 \mathrm{Ni}$, and $99 \mathrm{Tc}$ are not at this time measurable nondestructively in a sealed waste package, and 93Mo, 94 Nb, and $129 \mathrm{I}$ would be only marginally measurable under ideal conditions. These would include the absence of any other photon emitting radioisotopes -- a condition which is not likely to occur. Consequently, the only measurable radionuclides of interest are $60 \mathrm{co}, 90 \mathrm{sr}$, ${ }^{134} \mathrm{Cs}, 137 \mathrm{Cs}$, and transuranics, and the assay instrumentation should be designed specifically to measure these isotopes. The other long-lived activities will have to be determined by inference or by one of the other acceptable methods outlined in the NRC technical position paper. 


\section{INSTRUMENTAT ION}

The selection criteria for instrumentation have been defined in the preceding section, and can be summarized by saying that the system need be capable of measuring only $60 \mathrm{co}, 90 \mathrm{sr}, 134 \mathrm{cs}, 137 \mathrm{Cs}$, and transuranics. Of these, $60 \mathrm{co}$, ${ }^{134} \mathrm{Cs}$, and ${ }^{137} \mathrm{Cs}$ all emit monoenergetic high energy photons which can be measured accurately with a high resolution germanium diode gamma-ray spectrometer even in the presence of 1 arge quantities of other gamma-ray emitting radionuclides. Strontium-90 and its equilibrium daughter product, 90y, are both pure beta emitters and as such would not normally be considered measurable by gamma-ray spectrometry. However, the high energy beta particles emit copious quantities of Bremsstrahlung radiation during deceleration in the matrix material, and this Bremsstrahlung radiation can be detected with a germanium diode gamma-ray spectrometer. Due to the nature of the formation and use of $90 \mathrm{sr}$, when present in waste it is normally a major component which facilitates quantitative analysis. Data reduction for $90 \mathrm{Sr}$ assay will be discussed in more detail in the following section.

The four nuclides, ${ }^{60} \mathrm{co},{ }^{90} \mathrm{Sr},{ }^{134} \mathrm{Cs}$, and ${ }^{137} \mathrm{Cs}$, should be measured with a high resolution germanium diode gamma-ray spectrometer. There is no particular preference with regard to style, make, or type, but the preferred embodiment should be in a device commonly known as a segmented gamma scanner (SGS). The assembly and operation of this type of system incorporates a turntable that rotates the waste package through $360^{\circ}$ relative to the germanium diode while transversely scanning the waste package by either moving the turntable or the diode. Normally, rotational/translational rate ratios are such that "segments" on the order of a few centimeters thick are scanned, and the resultant spectra are summed to provide an "average" spectrum representing the entire waste package. This procedure is reasonably successful in compensating for inhomogeneous distributions and variations in the matrix density. Although no commercial instruments are currently available designed specifically for measurement of nuclides which can demonstrate compliance with 10 CFR 61, modifications to the software used with a system such as the Canberra Model 2220B could provide assay capability for high energy photon emitting fission product concentrations. Much more extensive modifications to the sof tware system could also provide quantitative ${ }^{90} \mathrm{Sr}$ concentration determinations, and the addition 
of a passive neutron detection system to the hardware, as well as additional data reduction capability, would be required in order to provide simultaneous quantitative assay of transuranic concentrations.

The selection criteria for measurement of transuranics are not as clear cut. First, transuranics include a broad spectrum of radioactive decays without any single feature in common. Only a few emit relatively high energy gammarays, and most of these are very low yield. Most decay by alpha particle emission accompanied by the corresponding $x$-rays, but neither of these radiations can be measured nondestructively from a typical sealed waste package. In fact, the only radiations from transuranics which are unequivocally measurable in the presence of other typical radionuclides are the neutrons emitted from fission or from $(\alpha, n)$ interactions in light isotopes present in the matrix material. These neutron emissions are commonly categorized passive (those emitted spontaneously by the waste) or active (those emitted following interrogation of the waste with pulsed neutron or photon sources).

Active neutron interrogation techniques measure either the prompt or delayed fission neutrons or the beta delayed neutrons from fission products following induced fission. These techniques normally only measure fissile transuranics (235u, 239 Pu, and $241 \mathrm{Pu}$ ) and are commonly applied only to contact handleable wastes(1-8), although application of the technique to high gamma activity wastes has been investigated $(9)$.

Passive neutron interrogation techniques, on the other hand, are capable of measuring all transuranics except $235 \mathrm{U}$ with adequate sensitivity and will work on both contact handleable and high gamma activity wastes. Although several different embodiments of this technology have been reported $(8,10-12)$, the general approach is to utilize neutron sensitive proportional counters, such as $10_{\mathrm{BF}}$ or $3 \mathrm{He}$, to record the total spontaneous neutron emission rate of the package and compare that to known standards for quantitative determination of the transuranic concentrations in the unknown package. Since the passive techniques are sensitive to a wider spectrum of transuranic isotopes than the active techniques and since they are substantially less complex and less expensive than the active systems, the passive neutron TRU assay technology is recommended for low-level waste assay instrumentation. The preferred embodiment would incorporate the neutron counters with the SGS system recommended for 
assaying the photon emitting nuclides. This could simply be an array of neutron counters around the rotating package to measure the neutron flux while the gamma-ray spectrum is being acquired. A drawing of such an instrument is shown in Figure 1.

Although most of the SGS and TRU assay systems described in the literature are for application to waste barrels, at least one neutron detection system has been applied to $4^{\prime} \times 4^{\prime} \times 8^{\prime}$ crates(13). It would be a relatively simple matter to include a scanning gemanium diode gamma-ray spectrometer in the crate counter for analysis of the photon emitting radioisotopes, and al though the entire system would be unwieldly large, its function would be similar to the proposed system for barrel analys is.

\section{MEASUREMENTS AND CALIBRATIONS}

Prior to analys is of an unknown waste package, it will be necessary to have calibrated the instrumentation using standard waste packages fabricated with known concentrations of radioactivities homogeneously distributed throughout selected matrices. A small computer for data handling and reduction as well as storage of reference and calibration data will greatly facilitate high throughput and reduce analytical costs. Standards containing ${ }^{60} \mathrm{Co},{ }^{134} \mathrm{Cs}$, and ${ }^{137}$ Cs in matrices with different densities, such as Dow modified vinyl ester binder and Portland cement, can be used to generate efficiency curves as a function of photon energy and matrix density. Analys is of an unknown waste package would begin by first identifying the gamma-ray emitting radioisotopes in the package based on the full energy photopeaks present in the spectrum. Next, the average matrix density of the unknown package would be determined on the bas is of spectrum shape. Basically, the procedure involves comparison of the relative intensity of different photopeaks from the same radioisotope and matching these ratios to those observed in standards of known density. This procedure for determining matrix density is preferable to the use of a transmission source for two reasons: 1) the measured density will more accurately reflect the localized environment in the vicinity of the radioactivity in case of inhomogenieties and 2) a transmission source may suffer interferences from activities present in the waste. A previously published discussion(14) of matrix effects on spectral shape demonstrates the wide range of sensitivity of this technique. Finally, the intensities of the full energy photopeaks in the 


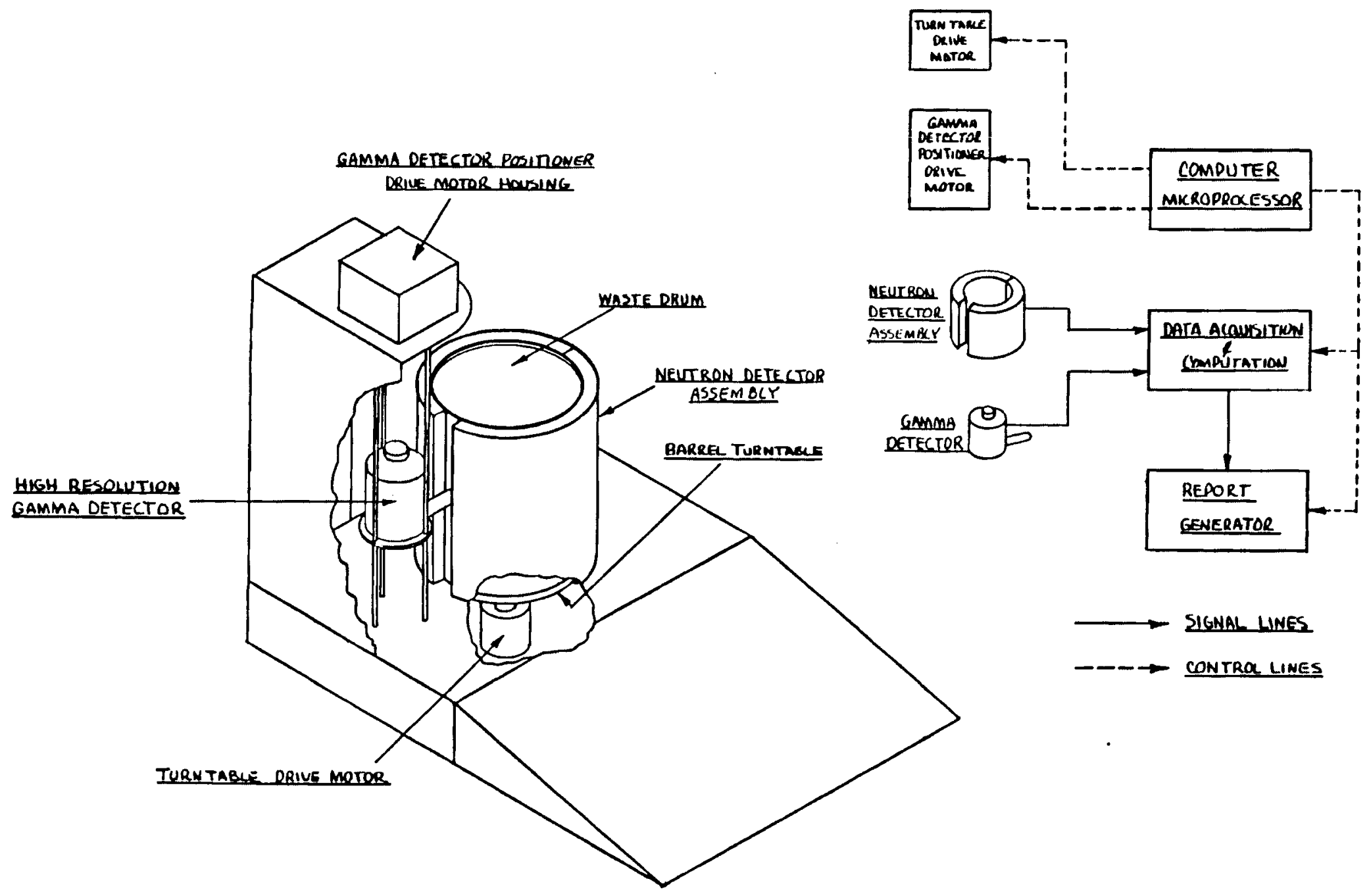

Figure 1. A Segmented Gamma Scanner Fit with Neutron Counters and Capable of Simultaneously Measuring Gamma-Ray Emitting Radionuclides, $90 \mathrm{Sr}$, and Transuranics. 
unknown are compared to the efficiency curve at the corresponding matrix density in order to determine the concentration of all gama-ray emitting radioisotopes identified in the waste package.

Next, the $90 \mathrm{Sr}$ concentration in the unknown waste package is determined with the aid of computer data reduction techniques which yield the absolute intensity of the Bremsstrahlung radiation. Basically, the procedure involves first identifying and quantifying the gamma-ray emitting isotopes present in the spectrum based on their full energy photopeaks and then "stripping out" each component utilizing an intensity normalized reference library spectrum leaving only $90 \mathrm{Sr}$ Bremsstrahlung radiation as the residual component. The $90 \mathrm{~S} r$ concentration is then determined by comparison to a library reference spectrum on the basis of intensity. The entire process requires acquisition of the net reference library of spectra from isotopically pure standards in various matrices so that their shape duplicates the corresponding component in the unknown spectrum, gain normalizing all spectra so that the photon energies in the unknown and reference spectra coincide, and intensity normalization so that subtraction of the various components is quantitative. The details of this data handling process are discussed elsewhere(15) and will not be repeated here.

Analys is of the transuranic content of unknown barrels is also accomplished by comparison to standards. The effects of matrix changes are much more severe in the case of neutron emissions since not only density but also moderation capability, high cross section neutron absorbing materials, and high neutron yield light isotopes such as fluorine have a profound effect on the neutron flux emitted by a waste package having a given transuranic isotope concentration. In addition, neutrons are emitted from both $(\alpha, n)$ interactions and spontaneous fission, and different mixtures of transuranics could yield identical neutron fluxes. Unfortunately, many of the matrix effects which impact the neutron yield are not determinable by nondestructive techniques. Although some sophisticated data acquisition and reduction techniques are being developed(12) which can locate inhomogenieties in transuranic isotope distributions, determine moderation and/or absorption qualities of the matrix, and independently quantify many transuranic isotope concentrations regardless of matrix effects, it will probably be most time and cost effective to compare 
neutron count rates in the unknown sample and the standard on a worst-possiblecase basis. This would provide a general screening of all barrels and a go/nogo decision regarding disposal could be made. Any waste packages which could conceivably contain more than $100 \mathrm{nCi} / \mathrm{g}$ of transuranic activities could then be withheld for more detailed analys is or designated potential transuranic waste.

\section{$\underline{\text { STANDARDS }}$}

In order to provide complete calibration capabilities for all low-level waste package assay instrumentation, it will be necessary to prepare standards in all conceivable package configurations, in a wide variety of matrix densities, and for each of the radioisotopes identifiable in the unknown packages. Practically speaking, packages should be confined to 30 and 55 gallon drums and $4^{\prime} \times 4^{\prime} \times 8^{\prime}$ boxes, and a few different matrices such as Dow modified vinyl ester binder and Portland cement should suffice.

Five 55 gallon drums have been filled with a single radioisotope homogeneously distributed throughout Dow modified vinyl ester binder using Dow Chemical Company proprietary procedures. The filled drums are used as standards and are available for instrument calibration. The author should be contacted to make arrangements for borrowing them or for nonproprietary details of the $f a b r i-$ cation process. Concentrations are approximately $10 \mathrm{mC} \mathrm{i} / \mathrm{m}^{3}$ for $60_{\mathrm{Co}}, 10 \mathrm{mC} / \mathrm{m}^{3}$ for ${ }^{90} \mathrm{Sr}, 14 \mathrm{mC} / \mathrm{m}^{3}$ for ${ }^{134} \mathrm{Cs}, 15 \mathrm{mC} \mathrm{i} / \mathrm{m}^{3}$ for $137 \mathrm{Cs}$, and $10 \mathrm{nC} / \mathrm{g}$ for transuranic alpha activity. 


\section{REFERENCES}

1. W. E. Kunz, J. D. Atencio, W. Bernard, G. C. Herrera, J. C. Pratt, and J. T. Caldwell, "A 1-mg-Sensitivity Fissile Assay System," LA-UR-81-1358, Los Al amos, New Mexico.

2. W. E. Kunz and J. T. Caldwell, "Current Status of the Multi-Isotopic Transuranic Waste Assay System," LA-UR-82-787, Los Alamos, New Mexico.

3. W. B. Bremner, K. C. Macleod, and P. C. Prentice, "The Design and Operation of Non-destructive Solid Waste Measurement Systems at DNPDE," TRG Memorandum 7342 (D), 1977, Windscale, United Kingdom.

4. W. E. Kunz, "Differential Dieaway Technique: Current Status of Los Alamos National Laboratory Work," Proceedings of TRU Waste Assay Instrumentation Workshop, May 23-24, 1983, Los Alamos.

5. L. A. Franks and S. M. Kocsimski, "LINAC Based TRU Assay," Proceedings of TRU Waste Assay Instrumentation Workshop, May 23-24, 1983, Los Alamos.

6. R. J. Critchley, N. Gardner, and G. B. Armitage, "Application of Differential Dieaway and Other NDA Nondestructive Assay Techniques to Selected Measurement Problems in the United Kingdom Nuclear Fuel Cycle," Proceedings of TRU Waste Assay Instrumentation Workshop, May 23-24, 1983, Los Alamos.

7. G. B. Armitage, "Harwell Experience with Dieaway Chamber Design, 208-1iter Barrel Effects, Neutron Tube Development, and Package Monitors, "Proceedings of TRU Waste Assay Instrumentation Workshop, May 23-24, 1983, Los Alamos.

8. T. W. Crane, "Measurement of Uranium and Plutonium in Solid Waste by Passive Photon or Neutron Counting and Isotopic Neutron Source Interrogation," LA8294-MS, 1980, Los Alamos, New Mexico.

9. J. T. Caldwell and W. E. Kunz, "Experimental Evaluation of the Differential Die-Away Pulsed-Neutron Technique for the Fissile Assay of Hot Irradiated Fuel Waste," LA-UR-82-788, Los Alamos, New Mexico.

10. R. L. Brodzinski, N. A. Wogman, H. L. Nielson, and D. P. Brown, "An Instrument for Determining the Transuranic Element Content of Chopped Leached Fuel Hulls and Other Materials," Proceedings of the 20th Annual Meeting of the Institute of Nuclear Materials Management, p. 438 (1979).

11. R. L. Brodzinski, "TRU Assay System and Measurements," Proceedings of TRU Waste Assay Instrumentation Workshop, May 23-24, 1983, Los Al amos.

12. L. A. Rogers, D. P. Brown and R. L. Brodzinski, "A Passive Neutron Counter for Determination of Transuranics in High Gamma Activity Samples, " 1983 IEEE Transactions on Nuclear Science.

13. E. R. Shunk, "Crated Waste Assay System," Proceedings of TRU Waste Assay Instrumentation Workshop, May 23-24, 1983, Los Al amos. 
14. H. L. Nielson, N. A. Wogman and R. L. Brodzinski, "In Situ Subterranean Garma-Ray Spectroscopy," Nucl. Instrm. Methods 143, 385 (1977).

15. R. L. Brodzinski and W. K. Hensley, "Well Logging Instrumentation for the In Situ Determination of $90 \mathrm{Sr}$, Tritium, and Transurani cs, " PNL-SA-10698 and ORNL/NFW-82/18, 1982, Pacific Northwest Laboratory, Richland, Washington 
PNL -4848

UC -70

\section{DISTRIBUTION}

No. of

Copies

$\underline{\text { OFFSITE }}$

27 DOE Technical Information Center

R. E. Cunningham

Office of Nuclear Safety Materials and Safeguards

Room 562

Nuclear Regulatory Commission

7915 Eastern Avenue

Silver Springs, MD 20910

J. B. Mart in

Division of Waste Management

Nuclear Regulatory Commission

Washington, DC 20555

R. Dale Smith

Division of Waste Management

Nuclear Regulatory Commission

Washington, DC 20555

T. C. Chee

$R \& D$ and Byproducts Division

DP-123 (GTN)

U. S. Department of Energy

Washington, DC 20545

W. F. Holcomb

National Institute of Heal th

Radiation Safety Branch

Building 21

Bethesda, MD 20205

J. A. Coleman, Director

Division of Storage and Treatment Projects

NE-25 (GTN)

U. S. Department of Energy

Washington, DC 20545
No. of

Copies

J. E. Dieckhoner

DOE Nuclear Waste Management Programs

NE30, B-107, HQ

Washington, DC 20545

J. J. Jicha, Director

R\&D and Byproducts Division

DP-123 (GTN)

U. S. Department of Energy

Washington, DC 20545

E. A. Jordan

Low-Level Waste Program

Manager

Division of Storage and

Treatment Projects

NE-25 (GTN)

U. S. Department of Energy

Washington, D.C. 20545

G. Oertel

DOE Nuclear Waste Management Programs

NE30, B-107, HQ

Washington, DC 20545

2 DOE Chicago Operations and Region Office

Argonne, IL 60439

Attn: S. A. Mann

F. Gorup

D. T. Oakley

Los Alamos Scientific

Laboratory

P.0. Box 1663

Los Alamos, NM 87544 
B. Lawless

DOE Savannah River Operations Office

P.0. Box A

Aiken, SC 29801

H. Saucier

DOE Savannah River Operations Office

P.0. Box A

Aiken, SC 29801

Len Lanni

DOE San Francisco Operations

1333 Broadway

Oakl and, CA 94612

R. Y. Lowrey

DOE Albuquerque Operations Office

P. 0. Box 5400

Albuquerque, NM 87185

D. M. Lund

DOE Albuquerque Operations Office

P.0. Box 5400

Albuquerque, NM 87185

2 Beverly Rawles

Battel le Memorial Institute

Office of Nuclear Waste Isol at ion

505 King Avenue

Columbus, $\mathrm{OH} 43201$

2 EG\&G Idaho

P.0. Box 1625

Idaho Fal ls, ID 83415

ATTN: G. B. Levin

R. H. Beers

P. Colombo

Dept. of Nuclear Energy

Brookhaven National

Laboratory

Upton, NY 11973
R. Williams

Electric Power Research Institute

3412 Hillview Avenue

P.0. Box 10412

Palo Alto, CA 94304

Environmental Protection Agency

Technological Assessment Division (AW-559)

Office of Radiation Programs

Washington, DC 20460

3 DOE Idaho Operations Office

550 Second Street

Idaho Falls, ID 84301

ATTN: C. P. Gertz

J. B. Whitsett

M. J. Barainca

2 DOE Oak Ridge Operations Office P.0. BOX E

Oak Ridge, TN 37830

ATTN: C. L. Mathews

D. E. Large

5 Oak Ridge National Laboratory P.0. Box X

Oak Ridge, TN 37830

ATTN: Central Research Library

R. B. Fitts

T. H. Row

J. E. Vath

L. J. Mezga

H. E. Filter

Larkin Laboratory

Dow Chemical U.S.A.

Midl and, MI 48640

2 Nevada Operations Office

U. S. Department of Energy

P. 0. Box 14100

Las Vegas, NV 89114

ATTN: R. Bol and

B. W. Church 
No. of

Copies

J. H. Kittel, Manager

Office of Waste Management

Programs

Argonne National Laboratory

9700 S. Cass Avenue, B1dg. 205

Argonne, IL 60439

R. R. Jaeger, Manager

Nuclear Waste Technology

Monsanto Research Corporation

P. 0. Box 32

Mianisburg, $\mathrm{OH} 45342$

R. E. Anderson

Goodyear Atomic

P. 0. Box 628

Piketon, $\mathrm{OH} 45661$

M. W. Boback, Director

Health and Safety Division

National Lead of Ohio

P. O. Box 39158

Cincinnati, $\mathrm{OH} 45239$

J. G. Couch

Fermi National Accelerator

Laboratory

P. D. Box 500

Batavia, IL 60510

T. Harvey

Mai 1 Stop L-262

Lawrence Livermore Nationa 1

Laboratory

P. D. Box 808

Livermore, CA 94550

E. W. Kenda11, Project Manager

Waste Management

REECO

P. 0. Box 642

Mercury, NV 89023

J. McMenamin

Mason and Hanger -

Silas Mason Co.

Pantex Plant

P. O. Box 30020

Amari110, TX 79177
No. of

Copies

C. E. Wickl and

Manager, Waste Operations

Rockwe 11 International

Rocky Flats Plant

P. 0. Box 464

Golden, CO 80401

C. S. Abrams, Manager

Radiological Engineering

Argonne National Laboratory-West

P. 0. Box 2528

Idaho Falls, ID 83401

E. L. Albenesius

Savannah River Laboratory

P. 0. Box A

Aiken, SC 29801

J. J. Blakes lee, Program Manager

Nuclear Waste Processing

Rockwe 11 International

P. 0. Box 464

Golden, CO 80401

J. Fischer

Low-Level Radioactive Waste Program

U. S. Geological Survey

12201 Sunrise Valley Drive

Reston, VA 22092

\section{ONSITE}

4 DOE Richland Operations Office

H. E. Ransom

P. F. X. Dunigan

G. Orten

J. J. Schreiber

2 Rockwe 11 Hanford Operations

J. F. Albaugh

J. L. Deichman 
Westinghouse Hanford Company

R. E. Lerch

42 Pacific Northwest Laboratory

R. L. Brodzinski (20)

T. D. Chikalla

D. W. Dragnich

G. W. Gee

W. A. Glass

T. L. Jones

L. J. Kirby

M. R. Kreiter

J. M. Nielsen

R. E. Nightingale

R. W. Perkins

A. M. Platt

J. V. Robinson

J. L. Swanson

H. H. Van Tuyl

N. A. Wogman

Technical Information (5)

Publishing Coordination (2) 